
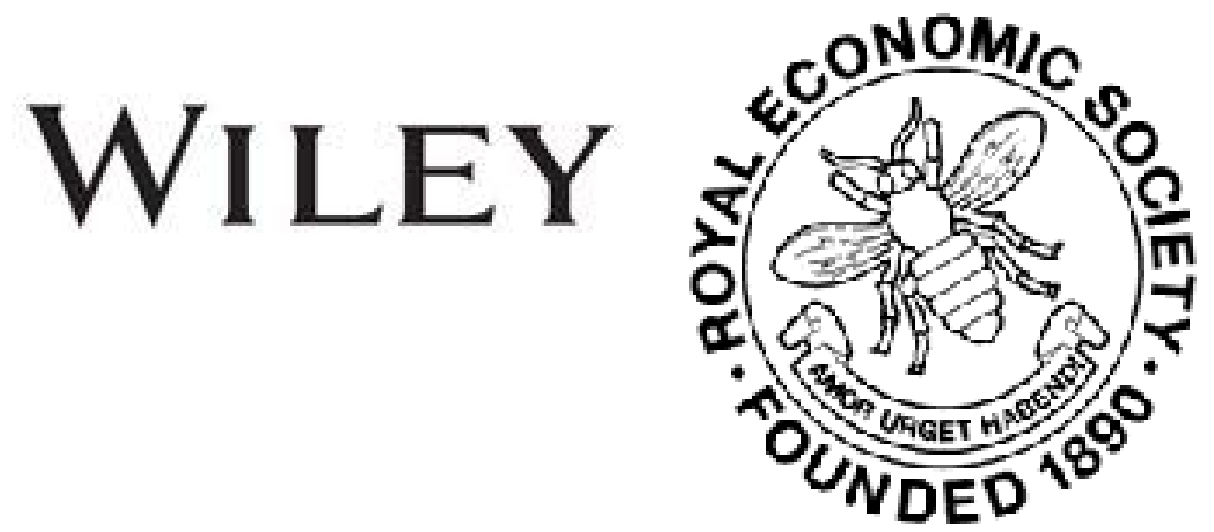

\title{
Co-operative Banking in Italy
} Author(s): Giuseppe Fiamingo

Source: The Economic Journal, Vol. 6, No. 22 (Jun., 1896), pp. 278-283

Published by: Wiley on behalf of the Royal Economic Society

Stable URL: http://www.jstor.org/stable/2956519

Accessed: 26-06-2016 06:20 UTC

Your use of the JSTOR archive indicates your acceptance of the Terms \& Conditions of Use, available at

http://about.jstor.org/terms

JSTOR is a not-for-profit service that helps scholars, researchers, and students discover, use, and build upon a wide range of content in a trusted digital archive. We use information technology and tools to increase productivity and facilitate new forms of scholarship. For more information about JSTOR, please contact support@jstor.org.

Wiley, Royal Economic Society are collaborating with JSTOR to digitize, preserve and extend access to The Economic Journal 


\section{Co-operative Banking in Italy.}

THE new order in economy, the humble beginnings of which were set on foot fifty-one years ago by a score of poor weavers in Rochdale, has grown and expanded after the manner of all great and lofty ideas, finding no effective barrier in either seas, mountains, or political frontiers. But it has fructified differently in different countries according to the particular wants it has best met in each. Co-operation in England has proved most successful in distribution ; in France it has done best in production, while in Germany and Italy the greatest. development has been in the direction of co-operative banking. What the work of Schultze-Delitzsch and Raffeisen has done for co-operative banks in Germany, the grand, disinterested labours of Professor Luigi Luzzatti, formerly Finance Minister, have effected for those in Italy. Founded and effectively organised by him, these little banks have not only held their own in the sharp and persistent economic crisis in Italy of yesterday and to-day, during which every institution of credit has either fallen or stood tottering, but have grown and prospered, proving a great boon to workmen on the one hand and to small tradesmen and agriculturists on the other.

The following table which I have taken from the latest statistics on banking for the people, published by the Royal Italian Board of Statistics, shows in great and eloquent detail the nature of the clientèle in question: -

\begin{tabular}{|c|c|c|c|c|c|c|c|c|c|c|c|c|}
\hline \multirow[b]{2}{*}{ Clients' profession. } & \multicolumn{2}{|r|}{1880.} & \multicolumn{2}{|r|}{1881.} & \multicolumn{2}{|c|}{1882.} & \multicolumn{2}{|r|}{1883.} & \multicolumn{2}{|r|}{1886.} & \multicolumn{2}{|c|}{1893.} \\
\hline & 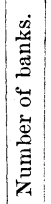 & 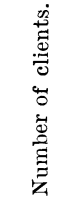 & 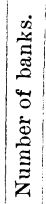 & 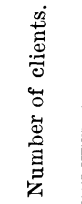 & 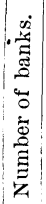 & 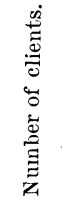 & 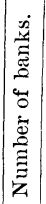 & 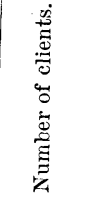 & 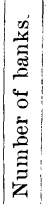 & 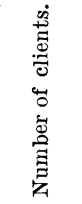 & 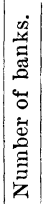 & 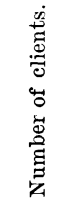 \\
\hline Large agriculturists...................... & 109 & 6,953 & 109 & 6,697 & 122 & 7,322 & 168 & 8,346 & 336 & 15.859 & & 24.160 \\
\hline Small agriculturists & 115 & 19,256 & 117 & 22,055 & 131 & 24,383 & 180 & 28,680 & $\left|\begin{array}{l}000 \\
361\end{array}\right|$ & 52,085 & $\left|\begin{array}{c}013 \\
565\end{array}\right|$ & 88,803 \\
\hline Day labourers.................................. & 74 & 3,188 & 82 & 3,009 & 92 & 3,269 & 124 & 4,125 & 257 & 9,708 & 380 & 17,165 \\
\hline $\begin{array}{l}\text { Large manufacturers and trades- } \\
\text { men ................................................ } \\
\text { Small trafactures and trades }\end{array}$ & 102 & 4,751 & 107 & 4,406 & 114 & 4,839 & 163 & 5,893 & 313 & 12,528 & 468 & 17,563 \\
\hline men & 117 & 28,941 & 120 & 23,172 & 134 & 25,450 & 187 & 31,185 & 386 & 64,569 & 596 & 92,963 \\
\hline $\begin{array}{l}\text { Operatives } \ldots \ldots \ldots \ldots \ldots \ldots \\
\text { Employees and professional per- }\end{array}$ & 113 & 8,492 & $11 i$ & 7,192 & 129 & 7,818 & $|173|$ & 10,116 & 309 & 22,788 & 455 & 29,864 \\
\hline $\begin{array}{l}\text { sons ...................................... } \\
\text { Persons of no settlosion }\end{array}$ & 116 & 15,530 & 120 & 12,909 & 133 & 13,625 & 187 & 17,172 & 387 & 32,036 & 614 & 69,423 \\
\hline 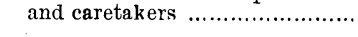 & 113 & 13,482 & 114 & 10,150 & 128 & 11,301 & 174 & 12,589 & 348 & 24,500 & 535 & 28,258 \\
\hline Total ..... & 121 & 100,593 & 121 & 89,590 & 135 & 98,007 & 189 & 118,106 & 399 & 234,073 & 639 & 368,199 \\
\hline
\end{tabular}

The actual number of clients of these banks in 1893 was 405,341, the table only giving the number of those whose profession was known. 
It will be seen that by far the greatest number of members are of the class of agriculturist, manufacturer, and tradesman on a small scale, while the smallest number is furnished by day labourers. M. Luzzatti has pointed out how closely the clientèle given above resembles that of similar banks in Germany. The latter is constituted as follows :-

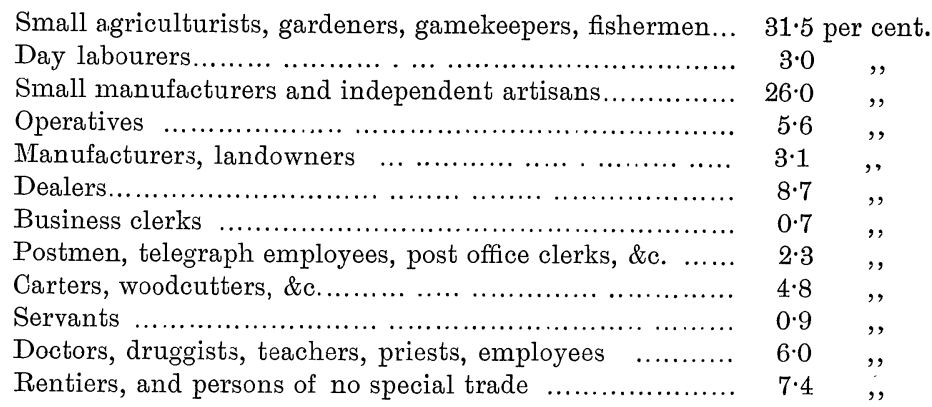

Now, if this proportionate distribution be compared with that in the Italian table, the resemblance appears to be striking. The same wants are evinced by similar manifestations ; those, namely, who take refuge in fraternal good faith are the outcasts of the large banks, and these, in Italy as in Germany, are mainly engaged in small manufactures, small trading and small agriculture. In our Italian table, for example, the last of these classes constitutes 24 per cent. of the whole, the first occupies 25 to 26 per cent., while day labourers have a percentage of $4 \cdot 66$ per cent.

According to D'Apel there was a 'people's bank' started at Montelupo Fiorentino as early as October, 1864. In April, 1865, one was licensed at Bologna, and soon developed into a flourishing concern. Professor Luzzatti lately pronounced it to be the best people's bank in the world. In 1894 its aggregate active transactions amounted to $35 \frac{1}{2}$ million francs, of which 28 millions were on personal guarantee alone, about 7 millions on deposits of value, and 626,000 were in rural current accounts. And the loss arising from all this activity has only been 3,323 francs, i.e. 11 centimes per thousand francs, let out on loan. In 1865 there were also founded the people's banks at Milan and at Cremona; and thus the number went on increasing steadily till in 1870 , when statistics about them were first collected, it already amounted to 50. These 50 banks had a 'patrimony' (circulating capital and reserve) of about 15 millions. The deposits in current accounts, reserve deposits, and interestbearing funds were 32 millions. The discounted bills were 25 millions and the reports 6 millions.

Another decade of slow growth brought the number of people's banks, in 1881, up to 171 with a capital of 53 millions. Between 1882 and 1887 they shot up to 608, with a capital of 104 millions. 
And then all the economic activity and development that was going on was paralysed by the failure of the Government in the attempt to renew the commercial treaty between Italy and France, a failure which anticipated and aggravated the agrarian crisis which had already been lowering over the country. Naturally the people's banks could not fail to be considerably affected thereby. And yet they continued to progress! In 1888 the number rose to 652 ; in 1889 to 672 ; in 1890 to 694. In 1891 there was no increase, but in 1892 they advanced to 718 and to 723 in 1893, falling however to 720 in 1894. In this year their 'patrimony' amounted to 114 millions-a decrease of 6 millions on the immediately preceding years-the deposits to 372 millions, the discounted bills to 214 millions, the advances to 29 millions. They owned also 136 millions in public funds and in industrial investments.

The average number of members per people's bank has been diminishing. In 1876 it was 943 ; that is to say, the number of people's banks that then published the number of their clients was 82 , the total membership being 77,340. In 1880 this average had fallen to 831 ; three more years brought it down to 718 , and yet four more (1887) to 590, but it rose again in 1893 to 612 . Of course this average has been reduced by the rise of small co-operative banks, while on the other hand it was sent up in consequence of some of these small concerns going under during the economic crisis. Indeed, the average 'patrimony' of each bank has been diminishing since 1876; that is to say, from 406,648 francs in that vear to 159,337 in 1894 .

The shares in these co-operative banks are each and all less than 100 francs, with the exception of those in two of them. Up to December, 1893, 17 had shares at 5 francs, 32 at 10 francs, 73 at 20 , 186 at 25,35 at 30,274 at 50 and 45 at 100 francs ; and there are in others shares intermediate in value to these. The total number of shares in the banks named below is 2,223,912; and the general average number of shares per member in all the co-operative banks of the country is 5.48 francs. In the following districts the average is higher: Liguria (23.17), Piedmont (9.29), Lombardy (7.79), Puglie (9.98), Sicily (9.76). It is not easy to say whether for the members to hold few or many shares is the more favourable symptom in general. If the shares are small, but there are many shareholders, this at least signifies that the co-operative idea is widely diffused and has a grip of the popular mind. The higher averages in Lombardy and Piedmont, however, are due precisely to the fact that co-operative institutions have thus proved very successful and have become an economic habit among the people, which is not the case in Sicily, Puglie, \&c.

It is significant that the chief transaction undertaken by these people's banks in Italy is the collecting single accounts and single advances. The subjoined table gives the percentage rate of the number of loans and discounts allowed in 1893 :- 


$\begin{array}{cccccc} & \begin{array}{c}\text { Up to } 200 \\ \text { frs. }\end{array} & \begin{array}{c}201-500 \\ \text { frs. }\end{array} & \begin{array}{c}501-1000 \\ \text { frs. }\end{array} & \begin{array}{c}1000-10,000 \\ \text { frs. }\end{array} & \begin{array}{c}\text { Above } 10,000 \\ \text { frs. }\end{array} \\ \text { Accounts........... } & 50 \cdot 27 & 26 \cdot 29 & 15 \cdot 75 & 7 \cdot 46 & 0 \cdot 23 \\ \text { Loans ............. } & 64 \cdot 02 & 20 \cdot 97 & 10 \cdot 18 & 4 \cdot 73 & 0 \cdot 10 \\ \text { Advances } \ldots \ldots \ldots . & \ldots & \ldots & 96 \cdot 81 & 2 \cdot 91 & 0 \cdot 28\end{array}$

Hence we see that the smaller transactions are absolutely more numerous than those on a larger scale, and also, if the preceding years be taken into account, tend to increase more than the latter.

Rightly to gauge the rate of development of the people's banks in different districts we must take into account not only their numerical growth but also the distribution of population and the importance in them of other institutions of credit. This has been carried out in the subjoined table :-

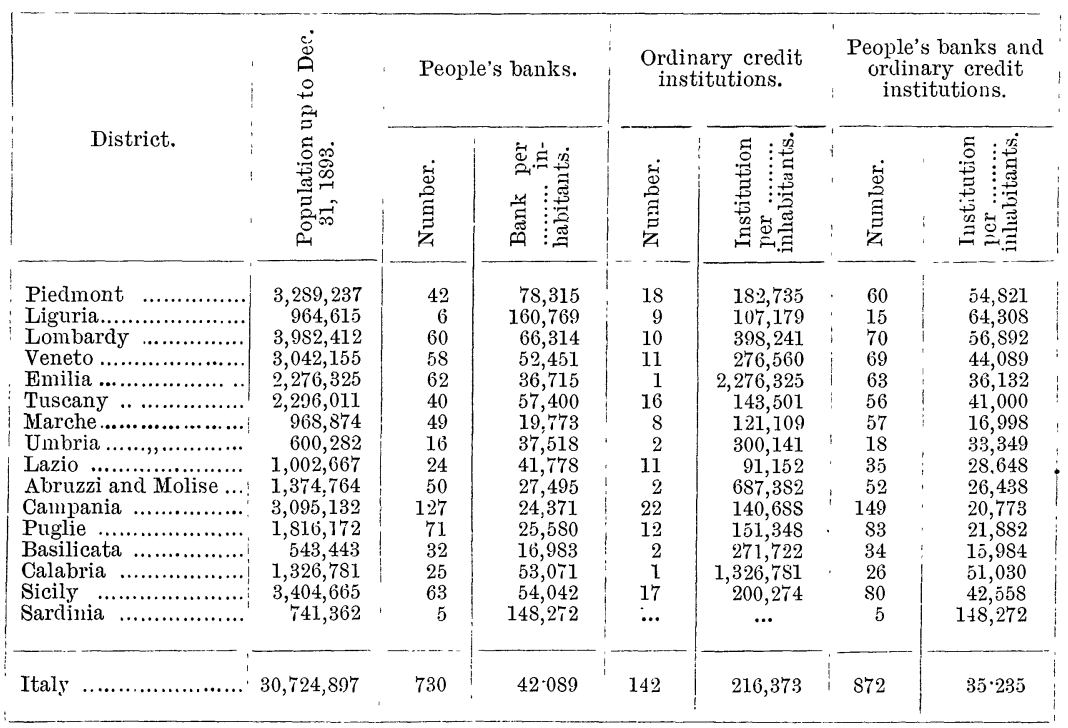

What is here most interesting is that the co-operative banks in proportion to the population of the different districts are much more numerous than other credit-institutions. This becomes more striking when we also take into consideration their respective rates of increase during recent years :-

$\begin{array}{cccc} & \text { People's banks. } & \text { Ordinary credit institutions } & \text { Total. } \\ 1881 & 171 & 113 & 284 \\ 1883 & 250 & 118 & 368 \\ 1887 & 608 & 155 & 763 \\ 1892 & 730 & 142 & 872 \\ 1894 & 720 & 144 & 864\end{array}$

Nor are the tables turned in favour of the latter when we consider the amount of 'patrimony' at the disposal of each. The average 
amount of deposit per head in all the people's banks in Italy is 12.04 francs, just 75 centimes higher than the average for all ordinary creditinstitutions taken together. This fact gains in significance when we consult the statistics of these deposits for the last few years :-

(In millions and thousands of francs.)

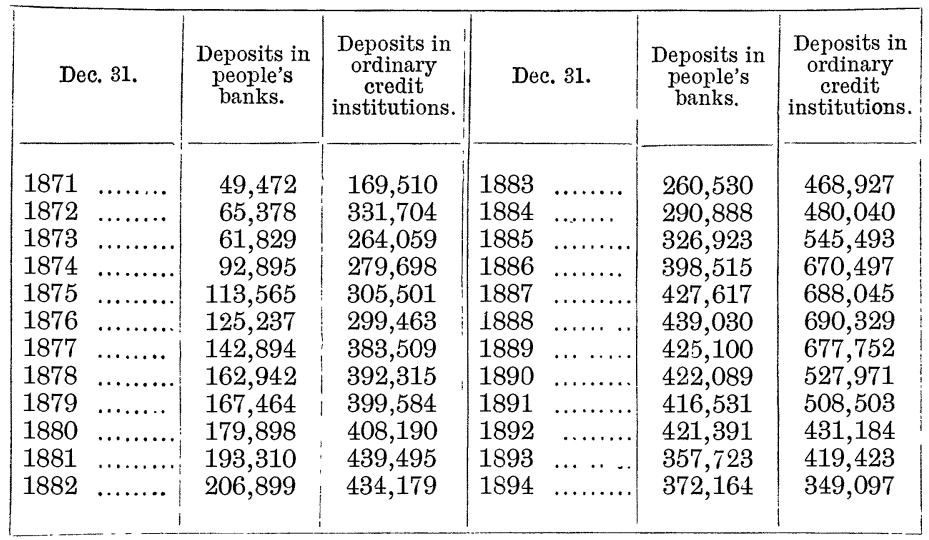

The table shows also how little the people's banks were affected by the recent economic crisis relatively to the ordinary credit-institutions.

We have here then a contrast full of useful suggestiveness: on the one hand an order of banking influenced and virtually directed by the Italian Government, the units in which are either ruined or have with difficulty maintained themselves and still lead a precarious existence; on the other hand another order, that of co-operative banking, practically ignored by Government, but free from its control, and entrusted only to the attentive, disinterested care of a few intelligent persons, headed by a distinguished scholar like Professor Luzzatti, yet prospering and developing splendidly in only thirty years, not only defying a general economic crisis, but beating all other credit-institutions put together. How great the power of initiative and individual will if left free from the shackles of State and bureaucracy!

One of the unfounded accusations brought against co-operative banks is that they impose enormous, sterilising rates of discount and interest, in contradiction to their professed principles. Now if we look at the rate of interest in the different banks of Europe (divided by Professor Luzzatti into three classes according as their rate is up to three, up to five, and over five per cent.) we find Italy usually in the second, and at the end of the year in the third, class. Of course the people's banks had to conform to this rate. They owe their rapid development precisely to the restricted credit obtaining in Italy. Could they fix their rate of discount at four per cent. when the official rate was five to six? This would have been an act of suicide. With one exception the proportion between insolvencies and the aggregate 
rate of loans and discounts has been kept at less than two per cent. In 1893 it was without exception 1.55 per cent. When some co-operative bank has raised its rate of discount too high, as in the case of that at Belpasso, where it once got to ten per cent., this brought down on it the swift and public reproof of Professor Luzzatti, who declared he could no longer consider it as a co-operative bank.

Thus the people's banks, by greatly facilitating the operations of the country's credit-market, without abusing that credit or falling short in their range of activity, have increased their net profits from 4,250,000 francs in 1880 to $6,514,000$ in 1893 . Of the latter amount. $4,827,854$ francs were distributed to the members of the 493 banks in dividends. The remainder was thus divided:-Ordinary reserve, 763,243 francs; extraordinary reserve, 393,512 francs; sum at the disposal of the Administrative Council bestowed in great part on benevolent and provident undertakings, 211,256 francs; specially distributed among employees, 379,738 francs; benefit, 107,529 francs; ready cash, 113,723 francs.

Nevertheless this wonderful record must not cause us to share the illusions of J. S. Mill. He believed in the advent of industrial peace as soon as working men should partake in the profits of capital and in management. Many still fall into this error, and we have witnessed Mr. Price lately inveighing against co-operation, because it had failed to realise all expectations.

The truth is that co-operation is a social institution which, when worked with care and on sane principles, can materially assist the working man and all other step-children of fortune who wish to ameliorate their position. Co-operation is not a socialistic, much less an ecclesiastical, institution; from these bodies hostilities have assailed her, and against them I for my part have had to fight. At her last congress, at Bologna, there were yet echoes of that fight, but they were echoes of victory and triumph. She, strengthened by struggle, goes her way, and goes forward, bearing aid to the worker so long as she remains free and individualist.

Giuseppe Fiamingo

\section{The German Insurance Laws. ${ }^{1}$}

IT is well known that even before the repressive legislation of 1878 the German Government were anxious to find some means of manifesting their practical interest in the welfare of the working classes. Such a counterblast to Socialist agitation became perhaps even more necessary when that agitation had been suppressed but not silenced. Dr.

1 For much that is contained in this paper I am indebted to the Report on the Labour Question in Germany drawn up by the Secretary to the Royal Commission on Labour, and to the original material from which that report is derived. 